\title{
Context Specificity and Time Dependency in Classifying Sub-Saharan Africa Dairy Cattle Farmers for Targeted Extension Farm Advice: The Case of Uganda
}

\author{
Elizabeth Ahikiriza ${ }^{1,2,3, *}$, Joshua Wesana ${ }^{4}\left(\mathbb{D}\right.$, Xavier Gellynck ${ }^{1} \mathbb{D}$, Guido Van Huylenbroeck ${ }^{1}$ (D) \\ and Ludwig Lauwers 1,5 (D)
}

1 Department of Agricultural Economics, Ghent University, 9000 Ghent, Belgium; Xavier.Gellynck@UGent.be (X.G.); Guido.VanHuylenbroeck@ugent.be (G.V.H.); ludwig.lauwers@ilvo.vlaanderen.be (L.L.)

2 Department of Agribusiness and Natural Resources Economics, Makerere University, Kampala P.O. Box 7062, Uganda

3 Faculty of Agriculture and Environmental Sciences, Mountains of the Moon University, Fort Portal P.O. Box 837, Uganda

4 Food and Markets Department, Natural Resources Institute, University of Greenwich, Chatham ME4 4TB, UK; J.Wesana@greenwich.ac.uk

5 Social Science Unit, Flanders Research Institute for Agricultural, Fisheries and Food (ILVO), 9820 Merelbeke, Belgium

* Correspondence: Elizabeth.Ahikiriza@UGent.be

check for updates

Citation: Ahikiriza, E.; Wesana, J.; Gellynck, X.; Van Huylenbroeck, G. Lauwers, L. Context Specificity and Time Dependency in Classifying Sub-Saharan Africa Dairy Cattle Farmers for Targeted Extension Farm Advice: The Case of Uganda. Agriculture 2021, 11, 836. https:// doi.org/10.3390/agriculture11090836

Academic Editor: Peter Tozer

Received: 29 July 2021

Accepted: 30 August 2021

Published: 31 August 2021

Publisher's Note: MDPI stays neutral with regard to jurisdictional claims in published maps and institutional affiliations.

Copyright: (c) 2021 by the authors. Licensee MDPI, Basel, Switzerland. This article is an open access article distributed under the terms and conditions of the Creative Commons Attribution (CC BY) license (https:/ / creativecommons.org/licenses/by/ $4.0 /)$.

\begin{abstract}
Despite the huge potential for milk production, interventions to improve productivity in sub-Saharan Africa (SSA) are barely based on specified farm classifications. This study aimed to develop robust and context-specific farm typologies to guide content of extension farm advice/services in Uganda. From a sample of 482 dairy farmers, we collected data on farmer socio-demographics, farm management practices, ownership of farm tools and facilities, willingness to pay for extension services, milk production, and marketing. Farm typologies were obtained based on principal component and cluster analyses. Thereby, of the three dairy production systems that emerged, small-scale, largely subsistence yet extensive and low productive farms were more prominent $(82.6 \%)$. Farms that were classified as large-scale, less commercialized yet extensive with modest productive systems were more than the medium-scale commercial farms with intensive and highly productive systems. However, the later were considered to potentially transform dairy farming in Uganda. It was also predicted that the validity of our farm classification may persist until half of the farms have moved between clusters. The study gives new insights on dairy production systems in Uganda, which can be used to organize more targeted research on farmers' extension needs for facilitating delivery of relevant and effective extension services and designing appropriate extension policies.
\end{abstract}

Keywords: dairy farms; farm typology; production systems; productivity; extension farm advice

\section{Introduction}

Despite the potential of the agricultural sector to accelerate growth and reduce food insecurity in sub-Saharan Africa (SSA) [1,2], production remains less optimal compared with developed countries [3,4]. Current projections show a $162 \%$ rise by 2067 in population, yet agricultural productivity will likely remain low [5,6], worsening food insecurity and poverty [7]. The improved use of livestock products, rich sources of protein, to transform food system outcomes for healthier diets, better nutrition, and sustainable livelihoods is a key pathway [8,9]. However, demand for animal sourced foods in SSA due to increased urbanization [10] is not often supported by growth in local production [11]. As such, livestock production needs to increase by $60-100 \%$ by 2050 [12], hence requiring considerable investments in infrastructure, agricultural research, and technology in SSA [13]. 
Agricultural extension and advisory services have been identified as crucial agents in agricultural development, poverty reduction, and food security [14-19]. Agricultural extension and advisory services can address production and management issues $[20,21]$ by enhancing farmers' technical knowledge, farm management skills, and effective information systems, leading to improved production, increased economic return, and a boost to the national and global economy [22-25]. In SSA, however, extension services and delivery methods tend to be ineffective in responding to the demands and technological challenges experienced by farmers [26-28]. The inability to account for context differences, unique across farmer needs, could explain the failure of timely transfer of relevant and reliable information to farmers [29]. Thereby, farmer complexity and diversity remain underperceived and undervalued in extension [30]. Like other farming systems, dairy production systems differ at regional and country levels in terms of technological and socioeconomic conditions [31]. Differences exist in current status of production systems, infrastructure, improvement techniques, productivity, and human capacity [32,33]. Given that different livestock farms can be heterogeneous between each other, yet still homogeneous within particular types [34,35], effective classification can inform extension services to facilitate agricultural development in SSA [36]. Hence, farm typologies can help generate context-specific improvement options and innovations at an individual country level $[37,38]$.

However, most previous typologies in the dairy sector at the individual country level were conducted on small ruminant (goat and sheep) production systems [37,39-45]. In addition to a focus on Europe and Latin America [46-49], dairy cattle production systems typologies are less common in SSA [50-52]. Moreover, livestock systems in the tropics and subtropics change rapidly; hence, past typologies tend to be irrelevant and inaccurate if applied to current systems [53]. However, no studies have been conducted to explain the best-before date of a farm typology [47]. Therefore, this study aimed to develop a robust context-specific farm typology by classifying farms in Uganda and assessing the best-before date of identified typologies. We aimed to assess whether (i) existing methods (such as participatory stakeholder involvement and traditional quantitative clustering techniques) could be combined to effectively and efficiently come to a context-specific classification; (ii) the obtained typology would be relevant for differentiated advice; and (iii) the typology would be robust enough to stand for a longer time.

The information generated from such a classification study could be vital for supporting the development of agricultural policies, extension programs, and technological solutions that are cautious of the context in which farmers operate to shape initiatives that improve farm management $[30,42]$. Furthermore, as it is difficult to accommodate the diversity of farmers with a single extension approach in most countries [54], such a study provides a better understanding of the diversity of dairy cattle production systems and thus would assist researchers, extension service providers, and policy makers in coming up with targeted interventions towards achieving increased agricultural productivity. Additionally, the results could further be used to design interviews for farmers who belong to different production systems to evaluate the current extension system and eventually design best-fit extension models for heterogenous farmers. Finally, such a differentiated view on production systems should increase awareness of the urgency to address specific constraints affecting different production systems and thus should improve policy recommendations.

The next section describes materials and methods used, with emphasis on how the classification of farms was conducted. The results in Section 3 not only describe the characteristics of the different dairy production systems but also present interpretations in terms of extension service needs and delivery methods. Section 4 discusses key findings illustrating whether the farm classes identified are relevant to facilitate the transfer of extension farm advice, the extent to which the classification methodology is able to capture context specificity, and whether farm classes identified are robust. Last, the final conclusions sum up key findings in Section 5. 


\section{Materials and Methods}

\subsection{Data Collection and Study Area}

Data were collected between August and September 2020 using a cross-sectional farmer household survey in Uganda. We targeted the districts of Mbarara, Ibanda, Kamwenge, and Kabarole to obtain a true representation of the dairy cattle keepers in Uganda, given the diversity in the selected districts. Based on face-to face interviews, a semi-structured questionnaire was pretested on 60 non-sampled farmers, adjusted as needed, and later administered to a random sample of 482 dairy farmers, selected from official farmer lists provided by the veterinary officer per district. A minimum of 112 dairy farmers were selected from each sampled district (Table 1). This sample was representative since the interviewed farmers were from the dominant dairy cattle-keeping sub-counties in these districts. Prior to each interview, respondents consented to the voluntary participation and were free to withdraw at any point during the interview. Since the interviews were conducted at the farm, it was also possible to make observations to triangulate with questionnaire responses.

Table 1. Farmer distribution in the sampled districts.

\begin{tabular}{ccccc}
\hline District & $\begin{array}{c}\text { Farmers } \\
\text { Interviewed }\end{array}$ & $\begin{array}{c}\text { Percentage } \\
\mathbf{( \% )}\end{array}$ & $\begin{array}{c}\text { Farmers Considered } \\
\text { for Analysis }\end{array}$ & Percentage (\%) \\
\hline Ibanda & 112 & 23.2 & 111 & 23.5 \\
Kabarole & 128 & 26.6 & 124 & 26.3 \\
Kamwenge & 121 & 25.1 & 118 & 25.1 \\
Mbarara & 121 & 25.1 & 118 & 25.1 \\
Total & 482 & 100.0 & 471 & 100.0 \\
\hline
\end{tabular}

\subsection{Variable Selection}

Considering that addressing heterogeneity depends on the nature of variables used to aggregate farms [55] and the process of variable selection [30,48], we adopted a four-step procedure to classify and characterize farms. First, a set of variables were derived from the literature on farm typology, including farm size, number of dairy cows, number of lactating cows, milk yield, labor intensity, stocking rate, amount of concentrates used, feeding/grazing systems used, herd size, farmer's experience, age at first mating, farmers' age, farm facilities and equipment, farm income, household size, hired labor, keeping animal records, milking frequency, farmer education level, use of artificial insemination, lactation period, and calving interval [37,42,49,50,56-63].

Second, stakeholders-i.e., sixty farmers and four area veterinary officers-were consulted to assess the relevance and suitability of variables obtained from the literature [51], given that no recent study on livestock system classification in Uganda was found in the study area. Furthermore, these stakeholders were involved because farm typologies solely based on surveys provide only a snapshot of farm situations [64]. Thereby, such typologies can rapidly become obsolete due to farm dynamics [65]. However, typologies that integrate local background and accumulated experience from the local participants tend to be more robust over time $[49,66]$. Subsequently, the resulting farm types change less over time, although individual farms may change from one farm type to another [48]. Thus, the methodology used in this study allowed for combining the opinions of the local stakeholders and the statistical methods to yield more dependable farm typologies. Stakeholder involvement was also done to account for differences in production systems, in line with recent recommendations [46,67-69]. Thereby, extracted variables that best differentiated the farmers were verified by sixty farmers and four area veterinary officers. No major differences in milking frequency among farmers were observed while renting land for dairy farming was less common. We observed inaccuracies in the measurement of labor, as farmers hardly remembered the amount of time dedicated to dairy farming. Thereby, stakeholders suggested alternative indicators, such as the number of permanent employees, salary paid for permanent and casual labor, and family members fully engaged in dairy 
farming, to replace man hours or annual worked hours, commonly used in the previous literature. Furthermore, most dairy farmers hardly kept farm records, so a question such as the quantity of milk produced in the dry season was adjusted to the quantity of milk produced on the very day of data collection, as it was easier for farmers to recall. Additionally, the number of dairy cows was preferred to the livestock units, as was used in previous studies $[37,42,70]$. Such insights and suggestions from stakeholders were used to improve the final questionnaire to ensure that the derived typologies reflected the context under study.

For the third step, we critically reflected and checked the quality of the data obtained from the preceding steps to ensure their relevance to the study objectives. This was in line with Köbrich et al. [34] as a useful step especially for studies in developing countries, where farm typology is usually derived from scratch. Thereby, variables that were selected earlier but lacked enough data would ideally be dropped so as not to bias subsequent classifications. However, all the variables were retained because they were supported by adequate data in this study.

Finally, exploratory data analysis was done to understand whether there was significant variability among the dairy cattle farmers based on the selected variables. According to Table 2, there was a high degree of variability among dairy farmers in the study area, hence justifying the need for classification. For instance, production scale, reflected by the amount of land allocated to dairy farming, highly differed, as some farmers only allocated 1 acre of land to dairy farming while others allocated even up to 260 acres, while majority allocated 31 acres. The number of dairy cows ranged between 2 and 210 cows and the quantity of milk produced ranged between 1 and 380L. In addition, the level of commercialization, indicated by the milk sold per day, differed-i.e., some farmers did not sell any milk at all, yet others sold up to $371 \mathrm{~L}$ of milk per day. The large farm variability revealed by the standard deviations prompted further analysis to classify farmers into more homogeneous farm types.

Table 2. General characteristics of the sampled dairy cattle farms.

\begin{tabular}{|c|c|c|c|c|c|}
\hline Variable Name & Min & Max & Mean \pm S.E & SD & CV (\%) \\
\hline Age of the major dairy farming decision maker (years) & 23.00 & 94.00 & $56.58 \pm 0.63$ & 13.64 & 24.1 \\
\hline Dairy farming experience (years) & 1.00 & 70.00 & $28.18 \pm 0.65$ & 14.17 & 50.3 \\
\hline Household size & 2.00 & 20.00 & $8.73 \pm 0.16$ & 3.45 & 39.5 \\
\hline Household land owned (acres) & 1.00 & 300.00 & $44.40 \pm 2.53$ & 54.95 & 123.8 \\
\hline Land allocated to dairy farming & 1.00 & 260.00 & $31.04 \pm 1.98$ & 43.07 & 138.8 \\
\hline Milk cow ${ }^{-1}$ day $^{-1}$ in dry season (L) & 0.50 & 19.70 & $6.36 \pm 0.17$ & 3.70 & 58.2 \\
\hline Milk cow ${ }^{-1}$ day $^{-1}$ in wet season (L) & 1.00 & 22.00 & $8.13 \pm 0.21$ & 4.27 & 52.5 \\
\hline Milk produced day ${ }^{-1}(\mathrm{~L})$ & 1.00 & 380.00 & $43.95 \pm 2.41$ & 52.41 & 119.2 \\
\hline Milk sold day ${ }^{-1}(\mathrm{~L})$ & 0.00 & 371.00 & $34.32 \pm 2.11$ & 46.00 & 134.0 \\
\hline Milk price $\mathrm{L}^{-1}$ in dry season (USD) & 0.10 & 0.33 & $0.23 \pm 0.001$ & 0.04 & 17.4 \\
\hline Milk price $\mathrm{L}^{-1}$ in wet season (USD) & 0.05 & 0.33 & $0.15 \pm 0.002$ & 0.05 & 33.3 \\
\hline Monthly milk sales (USD) & 0.00 & 2566.65 & $235.10 \pm 14.74$ & 320.41 & 136.3 \\
\hline Number of dairy cows & 2.00 & 210.00 & $25.78 \pm 1.27$ & 27.48 & 106.6 \\
\hline Number of lactating cows & 1.00 & 70.00 & $7.29 \pm 0.34$ & 7.40 & 101.5 \\
\hline Lactating cows/Dairy cows owned & 0.05 & 1.00 & $0.33 \pm 0.007$ & 0.15 & 45.5 \\
\hline Calving interval (months) & 10.00 & 21.00 & $13.75 \pm 0.11$ & 2.44 & 17.7 \\
\hline Age at first service (years) & 1.00 & 3.00 & $2.12 \pm 0.02$ & 0.37 & 17.5 \\
\hline Lactation period (months) & 5.00 & 18.00 & $9.25 \pm 0.12$ & 2.66 & 28.8 \\
\hline
\end{tabular}

Exchange rate: UGX 3676 = USD 1; monthly income from dairy computed based on time of data collection; S.E = standard error; $\mathrm{SD}=$ standard deviation; $\mathrm{CV}=$ coefficient of variation.

\subsection{Statistical Analyses}

Data were entered and cleaned using SPSS version 25 for statistical analysis. Initial checks for completeness resulted in the elimination of 11 farmers due to unrealistic (outlier) responses for the number of dairy cows, amount of land owned, and the amount of 
milk produced. Hence, analysis for this study was based on 471 dairy cattle farmers with complete and reliable information. From the initial variable classification, 13 variables were selected to aggregate the dairy farms in this study. This was done using Pearson correlation, principal component analysis (PCA), and cluster analyses (CA), as previously recommended [47]. Only quantitative variables were used to generate the principal components that were later used in CA to generate the farm types. However, categorical variables were later used to further characterize obtained clusters or production systems. PCA was used to combine variables into a smaller number of factors [71,72] as well as CA classified farmers into specific heterogenous clusters that were also homogeneous within [73]. To perform PCA, Kaiser-Meyer-Olkin (KMO) and Bartlett sphericity tests were used to check whether the dataset of 471 farm households and 13 variables were appropriate for PCA. The KMO test was 0.727 , which is greater than the 0.5 that is usually the lower threshold of the acceptable range, while the Bartlett's sphericity test was highly significant $(p<0.001)$, chi-square 2636.84 with 66 degrees of freedom. This shows that the technique was appropriate for this dataset. Additionally, the correlation matrix was generated as an identity matrix based on Bartlett's test of sphericity. Principal components (PCs) with eigen values greater than 1 (Kaiser's rule) [74], reflecting the diverse variables or indicators that determine the most important differences between the different groups, were retained [75]. From this analysis, a total of four components were retained for further analysis. A scree plot demonstrating the four components extracted from PCA is presented in Figure 1.

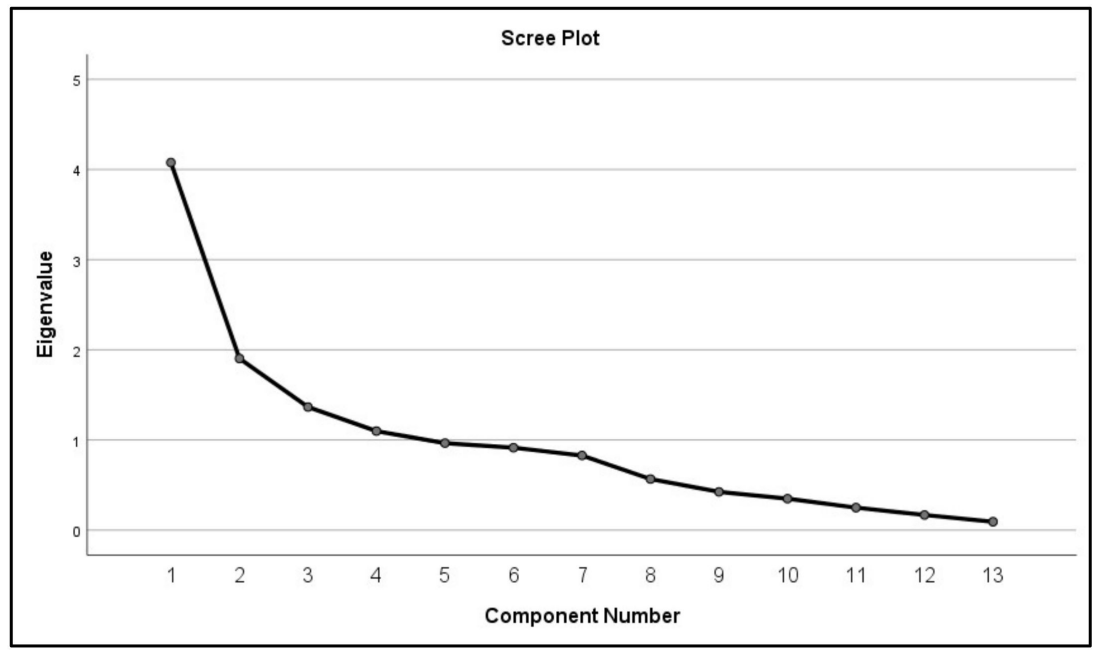

Figure 1. Scree plot showing the four principal components.

To enhance the discrimination of components, orthogonal varimax rotation with Kaiser normalization was used. The instruction to suppress small coefficients of absolute value below 0.5 was selected, which made it easy to know which variables were loading under a particular component. In line with Kamadi et al. [76], a split was made between factor loadings with values higher than 0.5 and lower than 0.5 to develop the basis on which to classify dairy cattle farms and to select variables for the hierarchical cluster analysis. These PCs explain up to $65 \%$ of the total variation (Table 3). The first PC explains the largest percentage of variation (21\%) after orthogonal rotation (varimax rotation), while the fourth PC explains only $9 \%$. 
Table 3. Initial eigenvalues, rotation sums of squared loadings of the PCs, and percentage of variance explained.

\begin{tabular}{|c|c|c|c|c|c|c|}
\hline \multirow[b]{2}{*}{$\begin{array}{l}\text { Principal } \\
\text { Components } \\
\text { (PC) }\end{array}$} & \multicolumn{3}{|c|}{ Initial Eigenvalues } & \multicolumn{3}{|c|}{ Rotation Sums of Squared Loadings } \\
\hline & $\begin{array}{c}\text { Total Eigen } \\
\text { Values }\end{array}$ & $\begin{array}{l}\text { Percentage of } \\
\text { Variance }(\%)\end{array}$ & $\begin{array}{l}\text { Cumulative } \\
\text { Percentage of } \\
\text { Variance }(\%)\end{array}$ & $\begin{array}{c}\text { Total Eigen } \\
\text { Values }\end{array}$ & $\begin{array}{l}\text { Percentage of } \\
\text { Variance (\%) }\end{array}$ & $\begin{array}{l}\text { Cumulative } \\
\text { Percentage of } \\
\text { Variance }(\%)\end{array}$ \\
\hline 1 & 4.08 & 31.36 & 31.36 & 2.72 & 20.95 & 20.95 \\
\hline 2 & 1.90 & 14.64 & 46.00 & 2.54 & 19.53 & 40.49 \\
\hline 3 & 1.37 & 10.51 & 56.51 & 1.98 & 15.25 & 55.74 \\
\hline 4 & 1.10 & 8.45 & 64.96 & 1.20 & 9.22 & 64.96 \\
\hline
\end{tabular}

Based on the variables that loaded heavily on different PCs (Table 4), the most important variables explaining PC1 include land for growing fodder and legume pastures, number of dairy cows, monthly milk sales, monthly household income, and monthly permanent hired labor costs, which largely reflected the level of commercialization of these farmers. PC2 is explained by land owned by the household, own land allocated to dairy farming, and the stocking rate, variables that can be taken as a measure of production scale and intensity. PC3 mainly explains productivity in terms of milk produced per cow per day, while PC4 explains the reproductive management practices of the farmers that are correlated with the dairy farming experience. This result shows that dairy cattle farms sampled for this study are characterized based on level of commercialization and management practices such as reproduction management, productivity levels, production scale, and intensity.

Table 4. Rotated component matrix for variables that define the extracted PCs considered for CA.

\begin{tabular}{|c|c|c|c|c|}
\hline Variables & PC1 & PC2 & PC3 & PC4 \\
\hline Land for growing fodder and legume pastures (acres) & 0.770 & & & \\
\hline Number of dairy cows & 0.632 & & & \\
\hline Monthly milk sales (USD) & 0.647 & & & \\
\hline Monthly household income (USD) & 0.554 & & & \\
\hline Monthly permanent hired labor costs (USD) & 0.817 & & & \\
\hline Land owned by the household (acres) & & 0.868 & & \\
\hline Own land allocated to dairy farming (acres) & & 0.881 & & \\
\hline Stocking rate & & 0.710 & & \\
\hline Milk produced cow ${ }^{-1}$ day $^{-1}$ (dry season) & & & 0.901 & \\
\hline Milk produced cow ${ }^{-1}$ day $^{-1}$ (wet season) & & & 0.893 & \\
\hline Calving interval (months) & & & & 0.544 \\
\hline Age at first service/mating (years) & & & & 0.622 \\
\hline Dairy farming experience (years) & & & & 0.574 \\
\hline
\end{tabular}

Two steps were followed to determine the number of clusters (i.e., the hierarchical and $k$-means clustering). Farms were grouped using hierarchical CA based on the principal components derived from PCA and then confirmed with the $k$-means CA. In hierarchical CA, Ward's method was used because it produced the most homogeneous groups. Furthermore, the squared Euclidean distance was used as a clustering measure. The number of clusters retained from Ward's method was used as starting values in the $k$-means method. Accordingly, the number of clusters that seemed most realistic and meaningful was chosen for the final solution. Table 5 shows the final cluster centers obtained from $k$-means CA. 
Table 5. Final cluster centers from $k$-means cluster analysis.

\begin{tabular}{cccc}
\hline Principal Component & Cluster $\mathbf{1}$ & Cluster 2 & Cluster 3 \\
\hline 1 & -0.24856 & -0.16130 & 2.99817 \\
2 & -0.27822 & -2.22415 & -0.32931 \\
3 & -0.00353 & 0.05564 & -0.05104 \\
4 & 0.02410 & -0.13174 & -0.07568 \\
\hline
\end{tabular}

To characterize the clusters from CA, one-way analysis of variance (ANOVA) and chi-square tests were performed. These tests were used to confirm statistical differences between the clusters.

\section{Results}

\subsection{General Characteristics of the Dairy Cattle Farmers}

Following the cluster analysis, dairy cattle farmers can be classified into three major production systems. The largest cluster constituted $82.6 \%$ of farmers, whose farms were characterized as small-scale, subsistence extensive, and low productive. Cluster 2 was represented by $11.5 \%$ of farmers, who were large-scale, less commercialized, extensive, and relatively productive, while cluster $3(5.9 \%)$ had medium-scale, commercialized, intensive, and highly productive farms. Although the three production systems are significantly different, they also share a few similarities with regards to the age of the major dairy farming decision maker, household size, lactation period, average amount paid to the extension agent at the last visit, and the monthly labor costs per cow (Table 6). Thereby, dairy farmers in the study area were generally old (mean age of 57 years). Hence, dairy farming potentially precludes youths, and so extension service interventions should be designed to account for a specific and relevant target group. Additionally, the lactation period of all production systems is within the acceptable range ( 8.3 to 9.6 months). Results further show that the cost of labor per cow across the three clusters in not statistically significant, despite being relatively higher for cluster 3 . However, the total costs of hired labor per month are significantly different among the three farm types: highest for cluster 3 farms (USD 189.6) and lowest for cluster 1 farms (USD 31.6). This can partly be explained by the widespread use of family labor for cluster 1 compared with cluster 3 farms that highly depend on hired labor. Moreover, cluster 3 farms have approximately three more permanently hired people than cluster 1 farms.

Table 6. Categorical variables that characterize the three dairy cattle farm types.

\begin{tabular}{|c|c|c|c|c|c|}
\hline Variable Name & Characteristic (\%) & $\begin{array}{l}\text { Cluster } 1 \\
(n=389)\end{array}$ & $\begin{array}{l}\text { Cluster } 2 \\
(n=54)\end{array}$ & $\begin{array}{l}\text { Cluster } 3 \\
(n=28)\end{array}$ & $\begin{array}{c}\text { Sig } \\
\text { (2 Sided) }\end{array}$ \\
\hline Keeping records & Yes & 54.2 & 72.2 & 96.4 & 0.000 \\
\hline Use of permanent hired labor & Yes & 75.5 & 92.6 & 96.4 & 0.001 \\
\hline \multirow{4}{*}{$\begin{array}{l}\text { Education level of the main } \\
\text { decision maker at the farm }\end{array}$} & No formal education & 10.9 & 22.2 & 7.4 & \multirow{4}{*}{0.002} \\
\hline & Primary education & 35.8 & 22.2 & 14.8 & \\
\hline & Secondary education & 26.5 & 22.2 & 18.5 & \\
\hline & Tertiary education & 26.8 & 33.3 & 59.3 & \\
\hline Use of artificial insemination & Yes & 5.6 & 10.0 & 28.6 & 0.004 \\
\hline $\begin{array}{l}\text { Growing fodder and legume } \\
\text { pastures on the farm }\end{array}$ & Yes & 29.6 & 43.7 & 64.3 & 0.010 \\
\hline \multirow{8}{*}{ Grazing system } & Tethering with no supplementary feeding & 0.8 & 0 & 0 & 0.727 \\
\hline & Tethering with irregular supplementary feeding & 0.3 & 0 & 0 & 0.900 \\
\hline & Tethering with regular supplementary feeding & 1.5 & 0 & 3.6 & 0.437 \\
\hline & Herding on own unfenced land with no supplementary feeding & 22.2 & 18.5 & 3.6 & 0.204 \\
\hline & Herding on own unfenced land with supplementary feeding & 17.8 & 20.3 & 10.6 & 0.027 \\
\hline & Own fenced paddocks with no supplementary feeding & 28.0 & 38.9 & 17.9 & 0.014 \\
\hline & Own fenced paddocks with supplementary feeding & 29.4 & 20.4 & 64.3 & 0.009 \\
\hline & Exclusive zero-grazing & 1.8 & 1.9 & 0.0 & 0.949 \\
\hline
\end{tabular}


Table 6. Cont.

\begin{tabular}{|c|c|c|c|c|c|}
\hline Variable Name & Characteristic (\%) & $\begin{array}{l}\text { Cluster } 1 \\
(n=389)\end{array}$ & $\begin{array}{c}\text { Cluster } 2 \\
(n=54)\end{array}$ & $\begin{array}{c}\text { Cluster } 3 \\
(n=28)\end{array}$ & $\begin{array}{c}\text { Sig } \\
\text { (2 Sided) }\end{array}$ \\
\hline WTP for extension services & Yes & 79.7 & 75.5 & 89.3 & 0.336 \\
\hline Smartphone ownership & Yes & 33.5 & 50.0 & 64.3 & 0.001 \\
\hline \multirow{4}{*}{ Tools/equipment } & Feed troughs & 42.6 & 45.5 & 46.4 & 0.983 \\
\hline & Strip cup & 1.0 & 5.6 & 14.3 & 0.000 \\
\hline & Chaff cutter & 3.6 & 7.4 & 21.4 & 0.000 \\
\hline & Solar powered/electric water pump & 1.8 & 5.6 & 11.1 & 0.008 \\
\hline \multirow{3}{*}{ Facilities } & Milking shed/parlor & 20.3 & 27.8 & 71.4 & 0.000 \\
\hline & Calf pen & 47.3 & 68.5 & 50.0 & 0.014 \\
\hline & Feed stores & 9.8 & 16.7 & 46.4 & 0.000 \\
\hline \multirow{4}{*}{ Milk marketing channel } & Middlemen & 34.4 & 25.9 & 32.1 & 0.144 \\
\hline & Cooperative society & 26.7 & 50.0 & 50.0 & 0.000 \\
\hline & Local consumers & 36.5 & 18.5 & 14.3 & 0.017 \\
\hline & Institution & 0.8 & 3.7 & 3.6 & 0.000 \\
\hline
\end{tabular}

Results further show a substantial number of farmers from all production systems $(80-89 \%)$ who are willing to pay for dairy advisory services, provided their production challenges are addressed. On average, cluster 3 farmers are willing to pay more for advisory services as compared with cluster 1 and 2 farmers. The amount paid to the extension agent at the last visit is not significantly different across the clusters. More interesting is the fact that in all the three clusters, the average amount farmers are willing to pay for the dairy advisory services is lower than what they paid the extension agent at the last visit. This result reliably communicates the views of the farmers regarding advisory services because the respondents clearly understood what was meant by farm advice in this study. A series of questions about the dairy advisory services were asked at the beginning of the interview-for instance, whether the farmer had ever received dairy advisory services, how often they received them, whom they received them from, major dairy extension services usually received, when the dairy extension agent last visited the interviewed farmer, and how much they paid the dairy extension agent the last time he was at their farm. Only after these questions were answered by farmers was a binary question asked, "Are you willing to pay for dairy extension services ?," followed by "How much are you willing to pay for dairy advisory services?" With this sequence of questions, and given the use of face-to-face interviews, the farmers were able to understand what was meant by advisory services. This way they were able to give answers from an informed point of view regarding whether they are willing to pay and how much they are willing to pay based on how much they were already paying to the dairy extension agents whenever they visited.

There were, however, lesser proportions unwilling to pay because they perceived that extension workers were already paid by the government. Despite a confirmation from area veterinary officers about government pay for the services that they provide, other essential items such as animal drugs are not facilitated, which attracts additional payments by farmers. Although there is a particular focus on treatment services rather than skills development in major farm management practices, dairy farmers still attach great value to current services with hopes of increasing productivity.

\subsection{Identification of Current Dairy Cattle Production Systems}

Based on 26 quantitative (Table 7) and 10 categorical (Table 6) variables, clusters obtained after the characterization process of dairy cattle farmers are explained below.

\subsubsection{Cluster 1}

This was the largest group of farmers, characterized by the lowest milk productivity per cow during both the wet and dry seasons. On average, 18 acres of land were allocated for dairy farming, including growing of fodder and legume pastures ( 0.3 acres). Grazing 
is majorly used, and farms are less dependent on supplementary feeding, so few farmers grew fodder and legume pastures (30\%). Farms also incur the highest annual cost for pests and disease management per cow (USD 23.7), partly due to increased pest and disease incidences, the poor feeding practices, and other important management practices. In addition, only $5.6 \%$ of farmers use artificial insemination (AI) because of cost, less trust in the origin of semen, low conception rates, limited AI services, unexpected outcomes (i.e., beef breeds), and increased mortality due to birth of large calves. Farms also had animals with relatively longer calving intervals, a possible reason for the low annual animal sales observed in 2019. Most farms also allowed calves to suckle before and after milking, with very few using bucket feeding, as reflected by the relatively low average amount of milk fed to the calves $(1.5 \mathrm{~L})$. The predominance of natural feeding was perpetuated by culture and tradition of these farmers. Regarding land, these farms had the lowest amount of land owned per household, which most likely limited the number of dairy cattle, and hence resulting in a moderate stocking rate (1.7). These farms scored lowest $(3.4 / 7)$ on the use of modern tools, facilities, and structures on their farms. For instance, only $9.8 \%$ had feed stores, $20.3 \%$ a milking parlor, $47.3 \%$ calf pens, and $1.8 \%$ had solar or electric powered water pumps on their farms. It was also observed that approximately 1 in 3 farmers owned smartphones, and just over half (54.2\%) kept farm records, particularly for milk sales. Considering the low productivity, farmers largely sell milk to local consumers and middlemen; hence, they earn the least per month.

Additionally, the general characteristics of cluster 1 results also show differences within the cluster, though these differences may be difficult to capture given that the clusters are considered as homogenous groups. For example, though the majority (35.8\%) of the farmers in the cluster had completed primary education as the highest level, there were other farmers $(26.8 \%)$ within the same cluster that had completed tertiary education. The grazing systems used by the farmers also varied, ranging from tethering (most extensive production method) up to exclusive zero-grazing (most intensive production method). Additional within-cluster variations were revealed by the cluster standard deviation, maximum, and minimum values of the quantitative variables. More significant variations were revealed in the age of the farm decision maker, the land owned by household, monthly milk sales, amount paid to the advisory at the last visit, and amount of money the farmers are willing to pay for the advisory services. 
Table 7. Quantitative variables that characterize the dairy cattle production systems.

\begin{tabular}{|c|c|c|c|c|c|c|c|c|c|c|}
\hline \multirow{2}{*}{ Name of the Variables. } & \multicolumn{3}{|c|}{ Cluster $1(n=389)$} & \multicolumn{3}{|c|}{ Cluster $2(n=54)$} & \multicolumn{3}{|c|}{ Cluster $3(n=28)$} & \multirow{2}{*}{ Sample Mean (SD) } \\
\hline & Min & Mean (SD) & Max & Min & Mean (SD) & Max & Min & Mean (SD) & Max & \\
\hline Age of the major dairy farming decision maker (years) & 23.0 & $56.0^{\mathrm{a}}(13.3)$ & 92.0 & 27.0 & $60.4^{\mathrm{a}}(15.0)$ & 93.0 & 32.0 & $58.6^{\mathrm{a}}(14.8)$ & 94.0 & $56.6(13.6)$ \\
\hline Dairy farming experience (years) & 1.0 & $26.9^{\mathrm{a}}(14.0)$ & 67.0 & 6.0 & $36.1^{\mathrm{b}}(14.1)$ & 70.0 & 3.0 & $31.3^{\mathrm{a}, \mathrm{b}}(11.9)$ & 58.0 & $28.2(14.2)$ \\
\hline Average monthly household income (USD) & 27.2 & $324.5^{a}(311.5)$ & 2720.4 & 122.4 & $662.1^{\mathrm{b}}(588.7)$ & 2720.4 & 136.0 & $2134.5^{\mathrm{c}}(933.0)$ & 4080.5 & $404.4(452.2)$ \\
\hline Land owned by the household (acres) & 1.5 & $27.6^{\mathrm{a}}(26.7)$ & 200.0 & 30 & $157.4^{\mathrm{b}}(71.7)$ & 300 & 7.0 & $61.4^{\mathrm{c}}(48.9)$ & 260.0 & $44.5(55.0)$ \\
\hline Land allocated to dairy farming (acres) & 1.0 & $17.9^{\mathrm{a}}(17.2)$ & 100.0 & 23.0 & $121.0^{\mathrm{b}}(64.5)$ & 260.0 & 4.0 & $41.75^{\mathrm{c}}(33.3)$ & 108.0 & $31.1(43.1)$ \\
\hline Land for fodder and pasture legumes (acres) & 0.0 & $0.3^{\mathrm{a}}(0.9)$ & 7.0 & 0.0 & $1.2^{\mathrm{b}}(3.1)$ & 15.0 & 0.0 & $3.3^{\mathrm{c}}(4.1)$ & 20.0 & $0.56(1.8)$ \\
\hline Stocking rate & 0.3 & $1.70^{\text {a }}(1.7)$ & 13.0 & 0.1 & $0.52^{\mathrm{b}}(0.4)$ & 2.6 & 0.7 & $2.46^{\mathrm{a}}(1.8)$ & 7.5 & $1.61(1.66)$ \\
\hline Lactation period (months) & 2.0 & $9.0^{\mathrm{a}}(2.7)$ & 15 & 4.0 & $8.3^{\mathrm{a}}(2.5)$ & 14 & 5.0 & $9.6^{\mathrm{a}}(2.3)$ & 18.0 & $8.9(2.7)$ \\
\hline Number of dairy cows & 2.0 & $18.2^{\mathrm{a}}(14.4)$ & 100.0 & 4.0 & $58.4^{\mathrm{b}}(39.6)$ & 136.0 & 13.0 & $68.4^{\mathrm{b}}(46.5)$ & 210.0 & $25.8(27.4)$ \\
\hline Milk cow ${ }^{-1}$ day $^{-1}$ in wet season (L) & 0.5 & $7.0^{\text {a }}(4.4)$ & 20.0 & 0.5 & $7.5^{\text {a }}(4.4)$ & 21.0 & 3.0 & $12.5^{\mathrm{b}}(5.7)$ & 22.0 & $7.4(4.7)$ \\
\hline Milk per cow ${ }^{-1}$ day $^{-1}$ in dry season (L) & 0.5 & $5.9^{\text {a }}(3.5)$ & 18.0 & 0.5 & $6.6^{\mathrm{a}}(3.9)$ & 18.0 & 1.0 & $10.4^{\mathrm{b}}(4.6)$ & 19.7 & $6.3(3.8)$ \\
\hline Milk fed to the calves ${ }^{-1}(\mathrm{~L})$ & 0.0 & $1.5^{\mathrm{a}}(4.1)$ & 30.0 & 0.0 & $2.0^{\mathrm{a}}(7.8)$ & 45.0 & 0.0 & $25.1^{\mathrm{b}}(25.4)$ & 104.0 & $3.0(9.4)$ \\
\hline Calving interval (months) & 10.0 & $13.8^{\text {a }}(2.5)$ & 21.0 & 10.0 & $13.0^{\mathrm{b}}(2.0)$ & 18.0 & 10.0 & $13.2^{\mathrm{a}, \mathrm{b}}(2.1)$ & 18.0 & $13.8(2.4)$ \\
\hline Age of first mating/service (years) & 1.0 & $2.1^{\mathrm{a}}(0.4)$ & 3.0 & 1.0 & $2.0^{\mathrm{b}}(0.4)$ & 3.0 & 1.0 & $2.0^{\mathrm{b}}(0.2)$ & 2.5 & $2.1(0.4)$ \\
\hline Milk price liter ${ }^{-1}$ (dry season) (USD) & 0.10 & $0.23^{\mathrm{a}}(0.04)$ & 0.33 & 0.16 & $0.22^{\mathrm{b}}(0.03)$ & 0.33 & 0.19 & $0.25^{\mathrm{c}}(0.03)$ & 0.33 & $0.23(0.4)$ \\
\hline Annual cost of pests and diseases management (USD) & 32.6 & $333.0^{\mathrm{a}}(235.6)$ & 1392.8 & 81.6 & $676.5^{\mathrm{b}}(429.7)$ & 1469.0 & 217.3 & $594.0^{\text {a }}(282.9)$ & 1305.8 & $387.9(293)$ \\
\hline Annual costs of pest and diseases cow ${ }^{-1}$ (USD) & 1.1 & $23.7^{\mathrm{a}}(17.4)$ & 163.2 & 1.5 & $15.68^{\mathrm{b}}(11.4)$ & 70.7 & 2.5 & $12.6^{\mathrm{b}}(11.4)$ & 61.2 & $22.1(16.9)$ \\
\hline Annual animal sales in 2019 (USD) & 0.0 & $1697.8^{a}(2777.5)$ & 33405.9 & 0.0 & $6025.72^{\mathrm{b}}(13,528.6)$ & $91,893.4$ & 0.0 & $4305.92^{\mathrm{c}}(4357.5)$ & $16,668.2$ & $2350.4(5502.5)$ \\
\hline No. of people permanently hired for dairy farming & 0.0 & $1.1^{\mathrm{a}}(1.1)$ & 3.0 & 0.0 & $2.6^{\mathrm{b}}(2.9)$ & 7.0 & 1.0 & $3.8^{\mathrm{b}}(2.2)$ & 9.0 & $1.4(1.6)$ \\
\hline Monthly hired labor costs (USD) & 0.0 & $31.6^{\mathrm{a}}(41.0)$ & 331.9 & 0.0 & $92.7^{\mathrm{b}}(96.1)$ & 448.9 & 13.6 & $189.6^{\mathrm{c}}(327.7)$ & 1768.2 & $48.1(101.6)$ \\
\hline Monthly hired labor costs cow ${ }^{-1}$ (USD) & 0.0 & $1.8^{\mathrm{a}}(2.1)$ & 17.5 & 0.0 & $1.8^{\mathrm{a}}(1.5)$ & 7.4 & 0.10 & $3.1^{\mathrm{a}}(3.9)$ & 19.7 & $1.9(2.2)$ \\
\hline Household size & 2.0 & $8.6^{\mathrm{a}}(3.4)$ & 20.0 & 2.0 & $9.4^{\mathrm{a}}(3.9)$ & 20.0 & 4.0 & $9.2^{\mathrm{a}}(3.8)$ & 17.0 & $8.7(3.4)$ \\
\hline Distance from home to the nearest trading center $(\mathrm{km})$ & 0.5 & $7.3^{\text {a }}(37.0)$ & 50.0 & 0.5 & $29.0^{\mathrm{b}}(52.7)$ & 65.0 & 1.0 & $2.5^{\mathrm{a}}(2.7)$ & 13.0 & $9.6(51.6)$ \\
\hline Rate of using modern farm tools and infrastructure (scale of 1-7) & 1.5 & $3.4^{\mathrm{a}}(1.7)$ & 5.5 & 2.0 & $4.4^{\mathrm{b}}(1.8)$ & 6.0 & 3.0 & $5.9^{\mathrm{c}}(1.9)$ & 6.0 & $3.7(1.8)$ \\
\hline Amount farmers are willing to pay for dairy advisory services (USD) & 0.27 & $9.6^{\mathrm{a}}(13.0)$ & 136.0 & 0.27 & $9.7^{\mathrm{a}}(8.8)$ & 54.4 & 2.7 & $19.9^{\mathrm{b}}(26.7)$ & 136.0 & $10.3(14.1)$ \\
\hline Amount paid to the extension agent at the last visit (USD) & 0.5 & $14.3^{\mathrm{a}}(17.0)$ & 163.2 & 1.1 & $21.4^{\mathrm{a}}(26.5)$ & 136.0 & 5.4 & $24.2^{\mathrm{a}}(30.2)$ & 136.0 & $15.7(19.5)$ \\
\hline
\end{tabular}

Exchange rate: UGX $3676=$ USD 1 at the time of data collection; $\mathrm{a}, \mathrm{b}, \mathrm{c}$ are significant at $p<0.01$ and $p<0.05$. 


\subsubsection{Cluster 2}

Dairy farmers in this cluster on average have the largest farms (121 acres), though with a relatively lower number of dairy cows, and hence a lower stocking rate (0.52). They, however, allocate significantly less land (1.2 acres) for the growing of fodder and legume pastures. Furthermore, farms exhibited a moderate milk productivity per cow, which is higher than that of cluster 1 but lower than cluster 3. Milk is often sold to a dairy cooperative $(50 \%)$ and to a lesser extent to middlemen (26\%). We also found that half of the farmers owned smartphones, while $72 \%$ kept farm records. Heifers for these farms take two years to mate, with a calving interval of 13 months, while only $10 \%$ of the farms reported using AI. We also observed that these farms have a moderate usage of modern farm tools, facilities, and equipment, rated at 4.4/7. On average, the cluster not only had the highest percentage of farmers who had not received any formal education but also had the largest difference between the amount that the farmers are willing to pay for the advisory services and what they had actually paid in the previous visit (USD 11.7). Finally, $93 \%$ of these farmers hire permanent workers on their dairy farms. Results also show that even though farmers in this cluster have an average of three permanent dairy farm workers, some farms have a much higher number (7). Additionally, the farmers within this cluster show variation in the location of their farms. For instance, most farms are located $29 \mathrm{~km}$ away from the nearest trading center, but the standard deviation of the distance from the farm to the nearest trading center is $50 \mathrm{~km}$ for this cluster.

\subsubsection{Cluster 3}

Farms in cluster 3 are more intensive, with a high stocking rate of 2.5. Thereby, most farms $(75 \%)$ combine natural grazing and supplementary feeding, supported by growing fodder and legume pastures. The use of maize bran is common, though normally spilled over the banana peelings, and so farmers are unaware of the specific quantity used per animal. However, a few $(<1 \%)$ use concentrates, hay, and silage. Cluster 3 farms mainly sell their milk to cooperative societies (50\%) and middlemen (32.1\%). The large majority (96\%) of farmers keep regular farm records, while $64.3 \%$ of them own smartphones (Table 6). On average, these farmers are rated at 5.9/7 in terms of using modern tools, facilities, and equipment. For instance, $71.4 \%$ of them have a milk shed /parlor, $46 \%$ feed stores, $14 \%$ strip cups, $11.1 \%$ electric powered pumps, and $21 \%$ chaff cutters. More than half of these farmers completed the tertiary level of education and fewer than one-third $(28.6 \%)$ of them use artificial insemination. Though the percentage of farmers using AI is still low, it is higher when compared with the other two clusters.

The above characteristics differentiate cluster 3 farmers from those of the other clusters, but results show that even within cluster 3 the farmers differ from each other in several ways. The most significant differences are reflected by the large standard deviations in the monthly household income, monthly milk sales, monthly hired labor costs, annual costs for disease and pest management, amount farmers are willing to pay for advisory services, and the amount they paid at the last visit.

\section{Discussion}

Our results identified three clusters of farms representing three distinct dairy production systems. These farms significantly differ in scale, farm management practices, milk productivities, utilization and ownership of modern farm tools and facilities, commercialization levels, and milk marketing channels. These differences indicate the uniqueness of such farms, which translates into specialized extension farm advice required to reduce production costs and improve productivity and farm management in general. For instance, farmers in cluster 1 would need extension farm advice that addresses the needs of smallscale farmers with limited land to allocate to dairy farming. The farmers in this cluster are as well characterized by use of more extensive production methods, such as limited use of supplementary feeding, AI, and bucket feeding, and they rarely keep farm records. 
These production system features are vital in guiding the advisors on the kind of extension farm advice required by such farmers. On the other hand, cluster 2 and 3 farmers also differ in observed management practices, resource ownership, social capital, knowledge, perceptions, and other social economic characteristics; hence, they would require advice that fits these characteristics. This result shows that the provision of more targeted extension farm advice is important, given the variations between the production systems. In agreement with this finding, Arouna et al. [77] reported that farm households that received personalized advice increased their yield by $7 \%$ and profit by $10 \%$, without increasing the quantity of production inputs, and hence by reducing inefficiencies.

Additionally, farm types differ in access to various social and physical assets that potentially influence the nature of appropriate extension service delivery methods. Thus, not only should the extension advice be context-specific, but also the delivery methods should be tailored to farm characteristics and access to assets [78]. For example, our study shows that while it may be very easy to train farmers in cluster 2 and 3 through utilization of the existing groups (i.e., dairy cooperative societies), given that the majority belong to such societies, this method may not be effective for cluster 1, where very few farmers are members. Similarly, the use of social media such as WhatsApp groups as a channel to deliver farm advice may not be effective for farmers in cluster 1 since only $34 \%$ of them own smartphones, and hence the need to emphasize targeted interventions suitable for specific dairy production systems $[58,79,80]$. In the same vein, Birner et al. [81] advised that advisory methodologies should not be standardized but rather should be adapted to the available resources, type of production system, and the complexity of the technologies promoted.

In addition to the heterogeneity between the clusters, our results reveal remaining heterogeneity within the clusters. Although average values are often used in classification to come up with recommendation domains [34], the remaining heterogeneity reveals that idiosyncratic characteristics should also be valued when offering farm advice and designing agricultural technologies. Researchers and extensionists/advisors should respond to this remaining diversity by developing a basket of options for highly diverse clusters so that farmers within such clusters may select the options that are best suited to their specific circumstances [82], hence the importance of understanding the heterogeneity within the clusters. This approach of offering a basket of options for such clusters enables farmers to decide on what is most suitable for their specific situations, and it reduces the burden for research and extension to develop recommendations that address thousands of possible situations [36,83].

The study additionally reveals the dominance of farms characterized as small-scale, subsistence, extensive, and low productive. This is in line with previous studies that also reported that most farmers in sub-Sahara African countries are small-scale and subsistence in nature $[46,84,85]$. Though some studies have found small-scale farms to be more productive and efficient $[86,87]$, others have challenged this finding, reporting that small farms are characterized by low efficiency, low productivity, and weak integration into the market [88-90]. This is in agreement with our study results that show that small-scale subsistence farms had the lowest milk productivity per cow, both in wet and dry seasons, and lowest household income.

Since subsistence farming is seen as an increasingly inefficient use of resources and small farms may struggle to prosper under increasing globalization, its reduction through accelerated appropriate policy interventions would be considered as a natural process of increasing productivity in the agricultural sector [91]. Moreover, in addition to the facilitation of designing a basket of options for this cluster, farm classification presents an analytical template for such inefficient farms to benchmark their production system against other farms in different production systems, which can result in the required policy interventions [92]. This facilitates farmers' self-reflection (Where am I?) to identify successful tactics and strategies used by other farm types (What can I change?) to achieve better performances (What improvement can I expect?) [48]. Self-reflection and 
the presence of a basket of options increases farmer learning and increases the motivation to adopt agricultural technologies that may help them produce more efficiently with the available resources.

Contrary to several studies [93-95] that found large-scale farms to be the most productive farms, our study found medium-scale dairy farms to have the highest productivity and best farm management practices. Hence, through benchmarking, self-reflection, and peer-to-peer extension methods, the less productive large-scale farmers in the study area could benchmark the best farm management practices from the medium-scale farmers within the same location, a finding that is supported by Jayne et al. [96], who reported that medium-scale farms have the potential to transform agriculture in sub-Saharan Africa. Additionally, Ahikiriza et al. [97] reported farmers' possibility of benchmarking across clusters to improve their farm production potential. Moreover, the large scale farmers already have most of the resources such as enough land, membership in cooperative societies, and smartphones that could be needed to improve their productivity. In addition to benchmarking and peer-to-peer extension methods, policy reforms targeting more affordable advisory services for this cluster should be thought about since farmers in the cluster were only willing to pay USD 9.7 for the services, yet they reported paying USD 21.4 on average at the previous visit by an advisor.

To maintain the high productivity of the medium-scale farmers and strengthen their ability to transform the dairy sector, the farmers in this cluster should be encouraged to maintain their willingness to pay for advisory services. Moreover, the difference between what these farmers actually paid for the services and what they were willing to pay did not largely differ. Increased willingness to use an advisory service can be further enhanced through price regulations by government to ensure that the services are not too expensive for the farmers who need to utilize them [98].

Although our study characterizes the current dairy production systems in Uganda, it is vital to note that these characteristics are dynamic and likely to change over time $[53,99]$. Such changes should therefore always be taken into consideration by the extension advisors, who should endeavor to update the training modules and methods of delivery of advice to the farmers, given the dynamic nature of the farming communities and their link to the adoption of the different innovations and interventions [82]. For instance, the farmers in cluster 1 are currently considered as resource-constrained traditional small-scale farmers, but with the use of the relevant advice derived from the aforementioned insights, some farmers can increase their scale or start using modern tools and equipment. Therefore, these movements of farmers across clusters need to be understood to avoid the use of obsolete advice on farmers who have already moved to another farm type.

Due to the inevitable movements of farmers across clusters, it is key to understand the best-before date of a farm typology [47]. The best-before date greatly depends on the rate at which the different indicators used to differentiate the production systems change [100]. In this study, it means that significant changes in productivity, commercialization levels, farm management practices, and production scale and intensity would render the typology less accurate, and this would necessitate conducting a new typology study. However, the changes in such indicators depend on how fast the farmers adopt and use the advice generated from the current farm classification [101].

Based on Rogers et al. [102], different farmers adopt interventions at different speeds. However, after the innovators, early adopters, and late majority have adopted, more relevant typologies/classifications may be considered. A significant number of farmers will have moved from one cluster to another; hence, the population will no longer be represented by the former classification that was the basis for developing the training modules that facilitated the movement of farmers from one cluster to another $[101,103]$. The period when the first half of the farmers have changed could be considered as an indication of the best-before date of a certain typology. At this point, researchers can consider developing a new typology, as those who have not yet adopted continue to learn from their peer networks. This may, however, not be possible without the strong farmer- 
extension-research linkages to keep all the actors informed. Therefore, such linkages should be encouraged and strengthened to ensure that more up-to-date classifications are used in designing advisory content, advisory methods, agricultural interventions, policies, technologies, and strategies.

Although Roger's innovation and diffusion theory [104] helps us to discuss the bestbefore date of our farm typology, the major limitation is that due to a lack of longitudinal data, our study is not able to predict the exact amount of time it will take for this farm classification to become obsolete. The study used cross-sectional data, and hence we could not apply discrete-time models to determine the exact shelf-life of the farm classification based on the adoption rate of different farm interventions. Therefore, future studies should use longitudinal data to determine the shelf-life of such farmer classifications. Furthermore, given that the determinants for the intention to use different farm technologies would influence the shelf-life of a farm classification, we recommend that future research uses recent technology acceptance theories to assess the factors influencing intention to use farm technologies, especially since smartphone-related technologies have steadily gained popularity in farming activities. Given that this study reveals differences in milk productivity across the identified production systems, it would be interesting for further studies to determine the factors influencing these differences in productivity. This would further guide the direction of the required extension farm advice.

The major strength of our study was the involvement of stakeholders in the development of study tools that helped to capture context-specific farm production systems. Additionally, the use of face-to-face interviews enabled observations about the status of the farms. The resulting classification was representative of the farm types, i.e., the classification matched the reality on the ground. The methodology followed the recommendation from Alvarez et al. [48] that suggested the use of local expert knowledge to create typologies. Therefore, this study concurs with Alvarez et al. [48] and Hammond et al. [47], in that the integration of local stakeholder knowledge and statistical methods in farm typology studies is necessary to obtain relevant farm typologies.

\section{Conclusions}

A relevant and robust farm classification was obtained from this study based on the combination of local stakeholder knowledge and statistical methods. Both methods and result (three distinct production systems) as developed and detected for the Ugandan case can be exemplary for broader SSA agriculture. The systems identified not only have obvious differences, such as productivity, commercialization level, production intensity, scale of production and farm management practices, but they also differ in terms of resource availability, social capital, knowledge, perceptions, and other social economic characteristics. These differences not only should be the basis for generating contextspecific extension advice but also should be the basis for designing appropriate extension delivery methods. Additionally, the within-cluster heterogeneity should not be overlooked but should rather be utilized to design a basket of options to assist in the delivery of relevant extension farm advice. It is observed that medium-scale farmers are driving the transformation of dairy farming in SSA, and this will likely persist in the future, considering the robustness of our farm classification. However, at the point when half of the farmers have moved from one cluster to another, the best-before date for a previous farm classification would ideally be reached, and so new farm typologies could be developed to support targeted extension services. Finally, the results of such classifications should be seen as a starting point from which to effectively evaluate the current extension system and eventually design the best-fit extension models for a heterogenous population of farmers. 
Author Contributions: E.A. contributed to the conceptualization, development of study tools, data collection, data processing, data analysis, drafting, and revision of the manuscript. J.W. contributed to the development of study tools, and reviewing and editing of the manuscript. X.G. contributed to the development of study tools, and reviewing and editing of the manuscript. G.V.H. contributed to reviewing and editing of the manuscript. L.L. contributed to the conceptualization, development of study tools, and reviewing and editing of the manuscript. All authors have read and agreed to the published version of the manuscript.

Funding: The authors are grateful to VLIR-UOS and DGD for supporting this work through the Flemish Interuniversity Council VLIR-UOS: ZIUS, 2013-2024, AP027 grant.

Institutional Review Board Statement: Ethical review and approval was not required for the study on human participants in accordance with local legislation because the data was completely anonymized.

Informed Consent Statement: All respondents/participants in the study provided their written informed consent to participate in this study.

Data Availability Statement: The datasets generated for this study are available on request to the corresponding author.

Conflicts of Interest: The authors declare no competing interests.

\section{References}

1. Aker, J.C. Dial "A" for agriculture: A review of information and communication technologies for agricultural extension in developing countries. Agric. Econ. 2011, 42, 631-647. [CrossRef]

2. Kondylis, F.; Mueller, V.; Zhu, J. Seeing is believing? Evidence from an extension network experiment. J. Dev. Econ. 2017, 125, 1-20. [CrossRef]

3. McIntyre, B.D.; Herren, H.R.; Wakhungu, J.; Watson, R.T. Agriculture at a crossroads: Global report. In International Assessment of Agricultural Knowledge, Science and Technology for Development (IAASTD); Island Press: Washington, DC, USA, 2009.

4. Ssozi, J.; Asongu, S.; Amavilah, V.H. The effectiveness of development aid for agriculture in Sub-Saharan Africa. J. Econ. Stud. 2019, 46, 284-305. [CrossRef]

5. Brandt, P.; Yesuf, G.; Herold, M.; Rufino, M.C. Intensification of dairy production can increase the GHG mitigation potential of the land use sector in East Africa. Glob. Chang. Biol. 2020, 26, 568-585. [CrossRef] [PubMed]

6. Britt, J.; Cushman, R.; Dechow, C.; Dobson, H.; Humblot, P.; Hutjens, M.; Jones, G.A.; Ruegg, P.S.; Sheldon, I.M.; Stevenson, J.S. Invited review: Learning from the future-A vision for dairy farms and cows in 2067. J. Dairy Sci. 2018, 101, 3722-3741. [CrossRef]

7. Adzawla, W.; Sawaneh, M.; Yusuf, A.M. Greenhouse gasses emission and economic growth nexus of sub-Saharan Africa. Sci. Afr. 2019, 3, e00065. [CrossRef]

8. Riggs, P.K.; Fields, M.J.; Cross, H.R. Food and Nutrient Security for a Growing Population. Anim. Front. 2018, 8, 3-4. [CrossRef] [PubMed]

9. Fróna, D.; Szenderák, J.; Harangi-Rákos, M. The challenge of feeding the world. Sustainability 2019, 11, 5816. [CrossRef]

10. Hatab, A.A.; Cavinato, M.E.R.; Lagerkvist, C.J. Urbanization, livestock systems and food security in developing countries: A systematic review of the literature. Food Secur. 2019, 11, 279-299. [CrossRef]

11. Herrero, M.; Havlik, P.; McIntire, J.; Palazzo, A.; Valin, H. African Livestock Futures: Realizing the Potential of Livestock for Food Security, Poverty Reduction and the Environment in Sub-Saharan Africa; Office of the Special Representative of the UN Secretary General for Food Security and Nutrition and the United Nations System Influenza Coordination (UNSIC): Geneva, Switzerland, 2014.

12. Thornton, P.K.; Jones, P.G.; Ericksen, P.J.; Challinor, A.J. Agriculture and food systems in sub-Saharan Africa in a 4 C+ world. Philos. Trans. R. Soc. A Math. Phys. Eng. Sci. 2011, 369, 117-136. [CrossRef] [PubMed]

13. Rosegrant, M.W.; Fernández, M.; Sinha, A.; Alder, J.; Ahammad, H.; Fraiture, C.; Eickhout, B.; Fonseca, J.; Huang, J. Looking into the Future for Agriculture and AKST (Agricultural Knowledge Science and Technology); Island Press: Washington, DC, USA, 2009; pp. 307-376.

14. Shiferaw, B.; Hellin, J.; Muricho, G. Improving market access and agricultural productivity growth in Africa: What role for producer organizations and collective action institutions? Food Secur. 2011, 3, 475-489. [CrossRef]

15. Asfaw, S.; Shiferaw, B.; Simtowe, F.; Lipper, L. Impact of modern agricultural technologies on smallholder welfare: Evidence from Tanzania and Ethiopia. Food Policy 2012, 37, 283-295. [CrossRef]

16. Elias, A.; Nohmi, M.; Yasunobu, K.; Ishida, A. Effect of agricultural extension program on smallholders' farm productivity: Evidence from three peasant associations in the highlands of Ethiopia. J. Agric. Sci. 2013, 5, 163. [CrossRef]

17. Kansiime, M.K.; Alawy, A.; Allen, C.; Subharwal, M.; Jadhav, A.; Parr, M. Effectiveness of mobile agri-advisory service extension model: Evidence from Direct2Farm program in India. World Dev. Perspect. 2019, 13, 25-33. [CrossRef]

18. Mariyono, J. Farmer training to simultaneously increase productivity of soybean and rice in Indonesia. Int. J. Product. Perform. Manag. 2019, 68, 1120-1140. [CrossRef] 
19. Danso-Abbeam, G.; Ehiakpor, D.S.; Aidoo, R. Agricultural extension and its effects on farm productivity and income: Insight from Northern Ghana. Agric. Food Secur. 2018, 7, 74. [CrossRef]

20. Butt, T.M.; Mahmood, K.; Muhammad, S. Working of commodity specialized extension approach followed by sugar mills in Faisalabad, Pakistan. J. Agric. Soc. Sci. 2005, 1, 252-254.

21. Wossen, T.; Abdoulaye, T.; Alene, A.; Haile, M.G.; Feleke, S.; Olanrewaju, A.; Manyong, V. Impacts of extension access and cooperative membership on technology adoption and household welfare. J. Rural Stud. 2017, 54, 223-233. [CrossRef] [PubMed]

22. Agbarevo, M.N.B. Farmers' perception of effectiveness of agricultural extension delivery in cross-river state, Nigeria. IOSR J. Agric. Vet. Sci. 2013, 2, 1-7. [CrossRef]

23. Feder, G.; Birner, R.; Anderson, J.R. The private sector's role in agricultural extension systems: Potential and limitations. $J$. Agribus. Dev. Emerg. Econ. 2011, 1, 31-54. [CrossRef]

24. Elahi, E.; Abid, M.; Zhang, L.; Ul Haq, S.; Sahito, J.G.M. Agricultural advisory and financial services; farm level access, outreach and impact in a mixed cropping district of Punjab, Pakistan. Land Use Policy 2018, 71, 249-260. [CrossRef]

25. Nettle, R.; Crawford, A.; Brightling, P. How private-sector farm advisors change their practices: An Australian case study. J. Rural. Stud. 2018, 58, 20-27. [CrossRef]

26. Davis, K. Extension in sub-Saharan Africa: Overview and assessment of past and current models and future prospects. J. Int. Agric. Ext. Educ. 2008, 15, 15-28.

27. Rivera, W.M.; Qamar, M.K.; Van Crowder, L. Agricultural and rural extension worldwide: Options for institutional reform in the developing countries. In Agricultural and Rural Extension Worldwide: Options for Institutional Reform in the Developing Countries; FAO: Rome, Italy, 2002; p. 54

28. Davis, K.; Nkonya, E.; Kato, E.; Mekonnen, D.A.; Odendo, M.; Miiro, R.; Nkuba, J. Impact of farmer field schools on agricultural productivity and poverty in East Africa. World Dev. 2012, 40, 402-413. [CrossRef]

29. Baloch, M.A.; Thapa, G.B. Review of the agricultural extension modes and services with the focus to Balochistan, Pakistan. J. Saudi Soc. Agric. Sci. 2019, 18, 188-194. [CrossRef]

30. Goswami, R.; Chatterjee, S.; Prasad, B. Farm types and their economic characterization in complex agro-ecosystems for informed extension intervention: Study from coastal West Bengal, India. Agric. Food Econ. 2014, 2, 5. [CrossRef]

31. Hernández-Castellano, L.E.; Nally, J.E.; Lindahl, J.; Wanapat, M.; Alhidary, I.A.; Fangueiro, D.; Grace, D.; Ratto, M.; Bambou, J.C.; De Almeida, A.M. Dairy Science and Health in the Tropics: Challenges and Opportunities for the Next Decades; Springer: Berlin/Heidelberg, Germany, 2019.

32. Opoola, O.; Mrode, R.; Banos, G.; Ojango, J.; Banga, C.; Simm, G.; Chagunda, M.G.G. Current situations of animal data recording, dairy improvement infrastructure, human capacity and strategic issues affecting dairy production in sub-Saharan Africa. Trop. Anim. Health Prod. 2019, 51, 1699-1705. [CrossRef] [PubMed]

33. Temoso, O.; Villano, R.; Hadley, D. Evaluating the productivity gap between commercial and traditional beef production systems in Botswana. Agric. Syst. 2016, 149, 30-39. [CrossRef]

34. Köbrich, C.; Rehman, T.; Khan, M. Typification of farming systems for constructing representative farm models: Two illustrations of the application of multi-variate analyses in Chile and Pakistan. Agric. Syst. 2003, 76, 141-157. [CrossRef]

35. Thornton, P.K.; van de Steeg, J.; Notenbaert, A.; Herrero, M. The impacts of climate change on livestock and livestock systems in developing countries: A review of what we know and what we need to know. Agric. Syst. 2009, 101, 113-127. [CrossRef]

36. Descheemaeker, K.; Ronner, E.; Ollenburger, M.; Franke, A.C.; Klapwijk, C.J.; Falconnier, G.N.; Wichern, J.; Giller, K.E. Which options fit best? Operationalizing the socio-ecological niche concept. Exp. Agric. 2019, 55, 169-190. [CrossRef]

37. Ibidhi, R.; Frija, A.; Jaouad, M.; Salem, H.B. Typology analysis of sheep production, feeding systems and farmers strategies for livestock watering in Tunisia. Small Rumin. Res. 2018, 160, 44-53. [CrossRef]

38. Otte, J.; Chilonda, P. Classification of cattle and small ruminant production systems in sub-Saharan Africa. Outlook Agric. 2003, 32, 183-190. [CrossRef]

39. Riveiro, J.; Mantecón, A.; Álvarez, C.; Lavín, P. A typological characterization of dairy Assaf breed sheep farms at NW of Spain based on structural factor. Agric. Syst. 2013, 120, 27-37. [CrossRef]

40. Toro-Mujica, P.; Aguilar, C.; Vera, R.; Rivas, J.; García, A. Sheep production systems in the semi-arid zone: Changes and simulated bio-economic performances in a case study in Central Chile. Livest. Sci. 2015, 180, 209-219. [CrossRef]

41. De Figueiredo, G.R.; Lima, A.M.C.; Alves, J.R.A.; da Costa, D.F.; Pinheiro, R.R.; Alves, F.S.F.; de Azevedo, S.S.; Alves, C.J. Characterization and typology of sheep and goat production systems in the State of Paraíba, a semi-arid region of northeastern Brazil. Semin. Ciências Agrárias 2017, 38, 2163-2178.

42. Gelasakis, A.; Rose, G.; Giannakou, R.; Valergakis, G.; Theodoridis, A.; Fortomaris, P.; Arsenos, G. Typology and characteristics of dairy goat production systems in Greece. Livest. Sci. 2017, 197, 22-29. [CrossRef]

43. Gelasakis, A.I.; Valergakis, G.; Arsenos, G.; Banos, G. Description and typology of intensive Chios dairy sheep farms in Greece. J. Dairy Sci. 2012, 95, 3070-3079. [CrossRef] [PubMed]

44. Rivas, J.; Perea, J.; Angón, E.; Barba, C.; Morantes, M.; Dios-Palomares, R.; García, A. Diversity in the dry land mixed system and viability of dairy sheep farming. Ital. J. Anim. Sci. 2015, 14, 3513. [CrossRef]

45. Castel, J.; Mena, Y.; Delgado-Pertıñez, M.; Camúñez, J.; Basulto, J.; Caravaca, F.; Guerrero, Y.M.; Alcalde, M.J. Characterization of semi-extensive goat production systems in southern Spain. Small Rumin. Res. 2003, 47, 133-143. [CrossRef] 
46. De Glanville, W.A.; Davis, A.; Allan, K.J.; Buza, J.; Claxton, J.R.; Crump, J.A.; Halliday, J.E.; Johnson, P.C.; Kibona, T.J.; Mmbaga, B.T.; et al. Classification and characterisation of livestock production systems in northern Tanzania. PLoS ONE 2020, 15, e0229478. [CrossRef]

47. Hammond, J.; Rosenblum, N.; Breseman, D.; Gorman, L.; Manners, R.; van Wijk, M.T.; Sibomana, M.; Remans, R.; Vanlauwe, B.; Schut, M. Towards actionable farm typologies: Scaling adoption of agricultural inputs in Rwanda. Agric. Syst. 2020, $183,102857$. [CrossRef]

48. Alvarez, S.; Timler, C.J.; Michalscheck, M.; Paas, W.; Descheemaeker, K.; Tittonell, P.; Andersson, J.A.; Groot, J.C. Capturing farm diversity with hypothesis-based typologies: An innovative methodological framework for farming system typology development. PLoS ONE 2018, 13, e0194757. [CrossRef] [PubMed]

49. Kuivanen, K.; Alvarez, S.; Michalscheck, M.; Adjei-Nsiah, S.; Descheemaeker, K.; Mellon-Bedi, S.; Groot, J.C. Characterising the diversity of smallholder farming systems and their constraints and opportunities for innovation: A case study from the Northern Region, Ghana. NJAS-Wagening. J. Life Sci. 2016, 78, 153-166. [CrossRef]

50. Defante, L.; Damasceno, J.C.; Bánkuti, F.I.; Ramos, C.E.C.O. Typology of dairy production systems that meet Brazilian standards for milk quality. Rev. Bras. Zootec. 2019, 48. [CrossRef]

51. Genís, J.M.C.; Madry, W.; Gozdowski, D.; Roszkowska-Madra, B.; Dabrowski, M.; Lupa, W.; Guerrero, Y.M. Family dairy farms in the Podlasie province, Poland: Farm typology according to farming system. Span. J. Agric. Res. 2010, 8, 946-961.

52. Maseda, F.; Diaz, F.; Alvarez, C. Family dairy farms in Galicia (NW Spain): Classification by some family and farm factors relevant to quality of life. Biosyst. Eng. 2004, 87, 509-521. [CrossRef]

53. Ramírez-Rivera, E.; Rodríguez-Miranda, J.; Huerta-Mora, I.; Cárdenas-Cágal, A.; Juárez-Barrientos, J.M. Tropical milk production systems and milk quality: A review. Trop. Anim. Health Prod. 2019, 51, 1295-1305. [CrossRef]

54. Klerkx, L.; Landini, F.; Santoyo-Cortés, H. Agricultural Extension in Latin America: Current Dynamics of Pluralistic Advisory Systems in Heterogeneous Contexts. J. Agric. Educ. Ext. 2016, 22, 389-397. [CrossRef]

55. Lacoste, M.; Lawes, R.; Ducourtieux, O.; Flower, K. Assessing regional farming system diversity using a mixed methods typology: The value of comparative agriculture tested in broadacre Australia. Geoforum 2018, 90, 183-205. [CrossRef]

56. Gonzalez-Mejia, A.; Styles, D.; Wilson, P.; Gibbons, J. Metrics and methods for characterizing dairy farm intensification using farm survey data. PLoS ONE 2018, 13, e0195286.

57. Bánkuti, F.; Prizon, R.; Damasceno, J.; De Brito, M.; Pozza, M.; Lima, P. Farmers' actions toward sustainability: A typology of dairy farms according to sustainability indicators. Animal 2020, 14, s417-s423. [CrossRef] [PubMed]

58. Baral, S.; Bardhan, D. Multivariate Typology of Milk Producing Households in Uttarakhand Hills: Explaining Profitability in Dairy Farming. Indian J. Agric. Econ. 2016, 71, 160-175.

59. López, C.J.Á.; Valiño, J.A.R.; Pérez, M.M. Typology, classification and characterization of farms for agricultural production planning. Span. J. Agric. Res. 2008, 6, 125-136. [CrossRef]

60. Belanche, A.; Martín-García, A.I.; Fernández-Álvarez, J.; Pleguezuelos, J.; Mantecón, Á.R.; Yáñez-Ruiz, D.R. Optimizing management of dairy goat farms through individual animal data interpretation: A case study of smart farming in Spain. Agric. Syst. 2019, 173, 27-38. [CrossRef]

61. Alemu, A.W.; Amiro, B.D.; Bittman, S.; MacDonald, D.; Ominski, K.H. A typological characterization of Canadian beef cattle farms based on a producer survey. Can. J. Anim. Sci. 2016, 96, 187-202. [CrossRef]

62. Gökdai, A.; Magrin, L.; Sakarya, E.; Contiero, B.; Gottardo, F. Characterization and typologies of dairy goat farms in the Mediterranean region: A case of Italy and Turkey. Small Rumin. Res. 2020, 191, 106196. [CrossRef]

63. Bereda, A.; Yilma, Z.; Nurfeta, A. Dairy production system and constraints in Ezha districts of the Gurage zone, Southern Ethiopia. Glob. Vet. 2014, 12, 181-186.

64. Kostrowicki, J. Agricultural typology concept and method. Agric. Syst. 1977, 2, 33-45. [CrossRef]

65. Valbuena, D.; Groot, J.C.; Mukalama, J.; Gérard, B.; Tittonell, P. Improving rural livelihoods as a "moving target": Trajectories of change in smallholder farming systems of Western Kenya. Reg. Environ. Chang. 2015, 15, 1395-1407. [CrossRef]

66. Landais, E. Modelling farm diversity: New approaches to typology building in France. Agric. Syst. 1998, 58, 505-527. [CrossRef]

67. Steinfeld, H.; Wassenaar, T.; Jutzi, S. Livestock production systems in developing countries: Status, drivers, trends. Rev. Sci. Tech. 2006, 25, 505-516. [CrossRef] [PubMed]

68. Marshall, K.; Gibson, J.P.; Mwai, O.; Mwacharo, J.M.; Haile, A.; Getachew, T.; Mrode, R.; Kemp, S.J. Livestock genomics for developing countries-African examples in practice. Front. Genet. 2019, 10, 297. [CrossRef] [PubMed]

69. Gerssen-Gondelach, S.J.; Lauwerijssen, R.B.; Havlík, P.; Herrero, M.; Valin, H.; Faaij, A.P.; Wicke, B. Intensification pathways for beef and dairy cattle production systems: Impacts on GHG emissions, land occupation and land use change. Agric. Ecosyst. Environ. 2017, 240, 135-147. [CrossRef]

70. Hanrahan, L.; McHugh, N.; Hennessy, T.; Moran, B.; Kearney, R.; Wallace, M.; Shalloo, L. Factors associated with profitability in pasture-based systems of milk production. J. Dairy Sci. 2018, 101, 5474-5485. [CrossRef]

71. Rolesu, S.; Loi, F.; Cappai, S.; Coccollone, A.; Cataldi, M.; Usala, P.; Podda, A.; Deliperi, S.; Oppia, P.; Natale, A.; et al. Description and typology of dairy sheep farm management profiles in Sardinia. Small Rumin. Res. 2018, 164, 39-47. [CrossRef]

72. Yerou, H.; Homrani, A.; Benhanassali, A.; Boussedra, D. Typological assessment of dairy farms systems in semi-arid Mediterranean region of western Algeria. Biotechnol. Anim. Husb. 2019, 35, 335-346. [CrossRef] 
73. Anderberg, M.R. Cluster Analysis for Applications: Probability and Mathematical Statistics: A Series of Monographs and Textbooks; New York Academic Press: New York, NY, USA, 2014.

74. Kaiser, H.F. Varimax solution for primary mental abilities. Psychometrika 1960, 25, 153-158. [CrossRef]

75. Mądry, W.; Mena, G.Y.; Roszkowska-Madra, B.; Gozdowski, R.; Hryniewski, R.; Castel, G.J.M. An overview of farming system typology methodologies and its use in the study of pasture-based farming system: A review. Span. J. Agric. Res. 2013, 11, 316-326. [CrossRef]

76. Kamadi, V.V.; Allam, A.R.; Thummala, S.M. A computational intelligence technique for the effective diagnosis of diabetic patients using principal component analysis (PCA) and modified fuzzy SLIQ decision tree approach. Appl. Soft Comput. 2016, 49, 137-145. [CrossRef]

77. Arouna, A.; Michler, J.D.; Yergo, W.G.; Saito, K. One size fits all? Experimental evidence on the digital delivery of personalized extension advice in Nigeria. Am. J. Agric. Econ. 2021, 103, 596-619. [CrossRef]

78. Lacombe, C.; Couix, N.; Hazard, L. Designing agroecological farming systems with farmers: A review. Agric. Syst. 2018, 165, 208-220. [CrossRef]

79. Dixon, J.A.; Gibbon, D.P.; Gulliver, A. Food and Agriculture Organization of the United Nations. Farming Systems and Poverty: Improving Farmers' Livelihoods in a Changing World; FAO: Rome, Italy; World Bank: Washington, DC, USA, 2001.

80. Sraïri, M.; Lyoubi, R. Typology of dairy farming systems in Rabat Suburban region, Morocco. Arch. Zootec. 2003, $52,47-58$.

81. Birner, R.; Davis, K.; Pender, J.; Nkonya, E.; Anandajayasekeram, P.; Ekboir, J.; Mbabu, A.; Spielman, D.J.; Horna, D.; Benin, S.; et al. From best practice to best fit: A framework for designing and analyzing pluralistic agricultural advisory services worldwide. J. Agric. Educ. Ext. 2009, 15, 341-355. [CrossRef]

82. Ronner, E.; Sumberg, J.; Glover, D.; Descheemaeker, K.; Almekinders, C.; Haussmann, B.; Kuyper, T.; Posthumus, H.; Ebanyat, P.; Giller, K. Basket of options: Unpacking the concept. Outlook Agric. 2021, 50, 116-124. [CrossRef]

83. Giller, K.E.; Tittonell, P.; Rufino, M.C.; Van Wijk, M.T.; Zingore, S.; Mapfumo, P.; Adjei-Nsiah, S.; Herrero, M.; Chikowo, R.; Corbeels, M. Communicating complexity: Integrated assessment of trade-offs concerning soil fertility management within African farming systems to support innovation and development. Agric. Syst. 2011, 104, 191-203. [CrossRef]

84. Mwanga, G.; Mujibi, F.; Yonah, Z.; Chagunda, M. Multi-country investigation of factors influencing breeding decisions by smallholder dairy farmers in sub-Saharan Africa. Trop. Anim. Health Prod. 2019, 51, 395-409. [CrossRef]

85. Martin-Collado, D.; Byrne, T.; Amer, P.; Santos, B.; Axford, M.; Pryce, J. Analyzing the heterogeneity of farmers' preferences for improvements in dairy cow traits using farmer typologies. J. Dairy Sci. 2015, 98, 4148-4161. [CrossRef]

86. Sanchez, F.M.A.; Restuccia, D.; Rud, J.P. Are small farms really more productive than large farms? Natl. Bur. Econ. Res. 2019. [CrossRef]

87. Fan, S.; Chan-Kang, C. Is small beautiful? Farm size, productivity, and poverty in Asian agriculture. Agric. Econ. 2005, 32, 135-146. [CrossRef]

88. Poczta-Wajda, A.; Sapa, A.; Stępień, S.; Borychowski, M. Food insecurity among small-scale farmers in Poland. Agriculture 2020, 10, 295. [CrossRef]

89. Davidova, S.; Fredriksson, L.; Bailey, A. Subsistence and semi-subsistence farming in selected EU new member states. Agric. Econ. 2009, 40, 733-744. [CrossRef]

90. Rada, N.E.; Fuglie, K.O. New perspectives on farm size and productivity. Food Policy 2019, 84, 147-152. [CrossRef]

91. Lipton, M. Staples production: Efficient "subsistence" smallholders are key to poverty reduction, development, and trade. In Agriculture and Rural Development in a Globalizing World; Routledge: London, UK, 2017; pp. 82-102.

92. Melcher, A.J.; Khouja, M.; Booth, D.E. Toward a production classification system. Bus. Process. Manag. J. 2002, 8, 53-79. [CrossRef]

93. Kokic, P.; Davidson, A.; Boero Rodriguez, V. Australia's grains industry: Factors influencing productivity growth. Aust. Commod. Forecast. Issues 2006, 13, 705-712.

94. Sheng, Y.; Zhao, S.; Nossal, K.; Zhang, D. Productivity and farm size in Australian agriculture: Reinvestigating the returns to scale. Aust. J. Agric. Resour. Econ. 2015, 59, 16-38. [CrossRef]

95. Sheng, Y.; Davidson, A.; Fuglie, K.; Zhang, D. Input substitution, productivity performance and farm size. Aust. J. Agric. Resour. Econ. 2016, 60, 327-347. [CrossRef]

96. Jayne, T.S.; Muyanga, M.; Wineman, A.; Ghebru, H.; Stevens, C.; Stickler, M.; Chapoto, A.; Anseeuw, W.; Van der Westhuizen, D.; Nyange, D. Are medium-scale farms driving agricultural transformation in sub-Saharan Africa? Agric. Econ. 2019, $50,75-95$. [CrossRef]

97. Ahikiriza, E.; Van Meensel, J.; Gellynck, X.; Lauwers, L. Heterogeneity in frontier analysis: Does it matter for benchmarking farms? J. Product. Anal. 2021, 1-16. [CrossRef]

98. Andreoli, M.; Gouerec, N. Tradition and Modernization in the Agricultural Development of a Tuscan (Central Italy) Marginal Area: The Role of Advisory and Extension Services. In Development Issues in Marginal Regions; Routledge: New York, USA, 2019; pp. 193-209.

99. Fraval, S.; Hammond, J.; Wichern, J.; Oosting, S.J.; De Boer, I.J.; Teufel, N.; Lannerstad, M.; Waha, K.; Pagella, T.; Rosenstock, T.S. Making the most of imperfect data: A critical evaluation of standard information collected in farm household surveys. Exp. Agric. 2019, 55, 230-250. [CrossRef]

100. Ronner, E. From Targeting to Tailoring: Baskets of Options for Legume Cultivation among African Smallholders. Ph.D. Thesis, Wageningen University, Wageningen, The Netherlands, 2018. 
101. Kuehne, G.; Llewellyn, R.; Pannell, D.J.; Wilkinson, R.; Dolling, P.; Ouzman, J.; Ewing, M. Predicting farmer uptake of new agricultural practices: A tool for research, extension and policy. Agric. Syst. 2017, 156, 115-125. [CrossRef]

102. Rogers, E.M.; Singhal, A.; Quinlan, M.M. Diffusion of Innovations; Routledge: New York, NY, USA, 2014.

103. Glover, D.; Sumberg, J.; Ton, G.; Andersson, J.; Badstue, L. Rethinking technological change in smallholder agriculture. Outlook Agric. 2019, 48, 169-180. [CrossRef]

104. Rogers, E.M. Diffusion of Innovations; Simon and Schuster: New York, USA, 2010. 